\title{
Jerzy Norbert Grzegorek, Animatorzy artystycznej kultury studenckiej w środowisku akademickim. Typologia ${ }^{1}$
}

Animator to osobistość, która pojawita się stopniowo obok kaznodziei, który już nie wystarczał, aby pobudzać ludzi do działania; pojawit się obok nauczyciela, który poczut się nagle zaatakowany przez animatorów dziatajacych obok szkoty i po szkole, kontestujacych rolę szkoty, poddajacych jego dziatalność nowym przemyśleniom, przedtużajacych ja; pojawit się obok działacza politycznego, który już nie potrafit animować społeczeństwa (Joffre Dumazedier za: Grzegorek, 2019, s. 50).

Ten opis szczególnej postaci, jaką jest animator, dość wyraziście ukazuje jego znaczenie w społeczeństwie jako osoby ożywiającej środowisko w przestrzeniach/wymiarach wartości często niezagospodarowanych, niedocenianych czy po prostu w nieoczywistych „światach życia”. Te „puste znaczące” (Laclau, 2004) dzięki animacji przeobrażają się w pewną formę reprezentacji, tworzą symbolikę w twórczym działaniu, ona zmienia też świadomość osób zaangażowanych w kreację danego środowiska. Świadomość wyjątkowej roli animatora szczególnie w środowisku akademickim stała się także przesłanką zwrócenia przez Jerzego Norberta Grzegorka uwagi badawczej i podjęcia przez niego badań, których głównym celem było uchwycenie i skonstruowanie typologii animatorów artystycznej kultury studenckiej w środowisku akademickim Szczecina.

Warto w tym miejscu przybliżyć samą postać autora tej oryginalnej monografii. Był on kierownikiem Akademickiego Centrum Kultury Uniwersytetu Szczecińskiego. Grzegorek to twórca spektakli, warsztatów tańca, choreograf, tancerz, nauczyciel akademicki, pedagog tańca, teoretyk i praktyk animacji kultury. Te artystyczne i pedagogiczne doświadczenia autora w środowisku akademickim, (auto)refleksja nad rolą „kreatora” miejsca/przestrzeni (zob. Grzegorek, 2019, s. 138), jak sam podkreśla, pokazują tło jego zainteresowań animacją i animatorami artystycznej kultury w środowisku akademickim.

1 Grzegorek, J.N. 2019. Animatorzy artystycznej kultury studenckiej w środowisku akademickim. Typologia. Toruń: Wydawnictwo Adama Marszałek, ss. 628. 
Monografia pt. Animatorzy artystycznej kultury studenckiej w środowisku akademickim. Typologia jest zwieńczeniem szeroko zakrojonych badań w środowisku artystycznym Szczecina, pod kierunkiem promotora prof. dr. hab. Dariusza Kubinowskiego, których rezultaty zostały przedstawione w rozprawie doktorskiej. Praca ta zaowocowała awansem naukowym w postaci uzyskania przez Grzegorka stopnia doktora nauk społecznych w zakresie pedagogiki.

Jest to z wielu powodów wyjątkowa publikacja. Po pierwsze jest to publikacja prezentująca pewną historię życia artystycznego Szczecina przez pryzmat biografii animatorów artystycznej kultury studenckiej (byłych i obecnych) poznanych dzięki wywiadom narracyjnym. Autor uwzględnił bogatą listę klubów studenckich już nie istniejących, uwzględnionych jako odniesienie historiograficzne odzwierciedlające nazwy używane przez dawnych animatorów w ich narracjach (Aneks, zestawienie nr 4). „Tło historyczne tych miejsc stanowi bogactwo dokonań poszczególnych ludzi, w tym zainicjowanej przez nich studenckiej tradycji artystycznej, która w pełni lub szczątkowej formie niejednokrotnie przetrwała do dnia dzisiejszego" (Grzegorek, 2019, s. 132).

W monografii zostały także uwzględnione kluby studenckie oraz inne miejsca/przestrzenie i instytucje, w których możliwe było podejmowanie działalności animacyjnej przez animatorów artystycznej kultury studenckiej (Aneks, zestawienie nr 3) a także uczelnie wyższe w Szczecinie (Aneks, zestawienie $n r$ 1) uwzględnione jako teren badań. Przy doborze przypadków uwzględniono także środowisko miejskie wraz z jego „kultowymi” miejscami (Grzegorek, 2019, s. 132). Jest to bardzo istotne dla ukazania i uchwycenia cech szczególnych świata/światów życia animatorów artystycznej kultury studenckiej.

„Jako terytorium aktywności podmiotu świat życia jest miejscem kontynuacji, aktualizowania i konstruowania nowych jego elementów. (...) Uczestniczenie w nim polega na interpretowaniu sytuacji (własnego położenia, konfiguracji poszczególnych elementów i relacji między nimi) oraz realizowaniu w tej sytuacji pewnych planów działania" (Czerepaniak-Walczak, 2006, s. 103). W obszarze kultury czyjś świat życia dzięki nawiązanej relacji może stać się początkiem zmiany w świecie życia innej osoby poprzez nowe wzory kulturowe, zmianę tradycji, wprowadzanie w nowe przestrzenie, animowanie.

Świat życia to bardzo nośna kategoria także dla uchwycenia przenikalności kultur, mozaikowości powiązań różnych kultur reprezentowanych przez różnorodne środowiska społeczne czy też jako kontekst edukacji międzykulturowej. Taką rolę społeczną spełniają animatorzy kultury, którzy uczą rozumienia innych poprzez ich kultury (Olbrycht, 2001, s. 115). Tego jest też 
świadom autor tej pracy, podejmując starania pozyskania jak największej grupy animatorów do badań. Jest to kolejny powód niepowtarzalności tej monografii, bowiem dzięki nawiązaniu przez autora wielu kontaktów i pozyskaniu wielu osób do wywiadów autor pozyskał imponujący materiał empiryczny, dzięki któremu wyłonił wiele kategorii analitycznych.

Rezultatem tych pogłębionych analiz zebranego materiału empirycznego jest bardzo obszerna objętościowo (628 stron), licząca siedem rozdziałów monografia. Praca podzielona jest na trzy części: teoretyczną, metodologiczną i empiryczną. Część teoretyczną tworzą dwa rozdziały, z czego pierwszy w syntetycznym ujęciu nawiązuje do animacji kultury jako humanistycznej koncepcji i praktyki pedagogicznej. Autor w ramach tego rozdziału prezentuje koncepcje działalności animacyjnej polskich i francuskich teoretyków i działaczy animacji w wymiarze społeczno-kulturalnym, jednak nie dokonuje podsumowań, nie prezentuje też krytycznego ustosunkowania się do tych zagadnień.

Na szczególne wyróżnienie zasługuje podrozdział 1.4. Animator kultury $w$ roli społecznej ze względu na ukazanie mozaikowości ról, funkcji, przestrzeni działania animatora kultury. Jak podkreśla sam autor:

Misja współczesnych animatorów, a tym samym pełniona przez nich rola społeczna może - jak sądzę - sprowadzać się do ciągłego podejmowania prób wypracowania efektywnych i alternatywnych - w stosunku do obowiązującego, instytucjonalnego systemu nauczania - dróg rozwoju edukacji kulturalnej i aktywności środowiskowej (Grzegorek, 2019, s. 57).

Myślę, że jest to istotne w odniesieniu do zjawisk związanych globalizacją kulturową. Agnieszka Roguska podkreśla wagę odwrócenia sił oddziaływania w edukacji kulturowej. Jej zdaniem:

Zamiast niwelować czy łagodzić skutki globalizacji kulturowej, w tym medialnej, podążać w kierunku wzmacniania funkcjonowania tego, co wartościowe, wspomagające ogólny rozwój człowieka. Otoczyć szczególną dbałością m.in. kultury mniejszościowe, kultury poszczególnych regionów wydobywając ich koloryt z udziałem partnerów lokalnych, w tym mediów środowiskowych (Roguska, 2012, s. 24).

Te siły oddziaływań mieszczą się w gestii między innymi animatorów kultury działających w konkretnym środowisku, animując lokalnie. Świetnym przykładem jest aktywność animatorów w środowisku akademickim przyczyniający się do aktywnego uczestnictwa w kulturze. Artystyczna kultura studencka jest problematyką drugiego rozdziału. Jest to przegląd różnych 
stanowisk teoretycznych dotyczących aktywności kulturalnej, istoty kultury studenckiej, roli sztuki w realizacji działania twórczego studentów oraz prezentacja badań empirycznych nad artystyczną kulturą studencką. Autor również w tym rozdziale ograniczył się głównie do prezentacji stanowisk, sam nie dokonując podsumowań ani odniesień krytycznych.

Część metodyczną pracy tworzy rozdział trzeci prezentujący podstawy metodologiczne badań osadzonych w paradygmacie interpretatywnym nauk społecznych. Podstawę zrealizowanych badań stanowi pedagogika zorientowana humanistycznie. Celem badań uczynił poznanie, przeanalizowanie i opisanie doświadczeń biograficznych żyjących animatorów, byłych i obecnie działających w środowisku akademickim Szczecina. Autor z wielkim pietyzmem i detalami prezentuje i opisuje w kolejnych podrozdziałach wszystkie etapy pracy badawczej. Dzieli się także swoimi doświadczeniami w trakcie pozyskiwania materiału empirycznego, który ze względu na konieczność rozpoznania dość obszernego terenu badań, jak i nawiązania kontaktu z wieloma osobami (300 bezpośrednich kontaktów,) pokazuje dużą determinację autora i jego zaangażowanie. Jak sam podkreśla, „Ja” badacza jest tu istotne: „Moje uwarunkowanie autobiograficzne miało zatem - jak sądzę - zasadnicze znaczenie w procesie poznania i lepszego rozumienia badanej rzeczywistości" (Grzegorek, 2019, s. 138). Ta sumienność badacza w szczegółowych opisach „kuchni” badacza, jak ujął to jeden z recenzentów pracy, dr hab. Bogdan Idzikowski (okładka książki), to cenne informacje o warsztacie badawczym dla innych badaczy zjawisk kulturowych.

Grzegorek pozyskał imponujący jakościowo i ilościowo materiał empiryczny w drodze wielogodzinnych wywiadów $\mathrm{z}$ animatorami i animatorkami artystycznej kultury studenckiej (trwały średnio sześć, siedem godzin każdy, Grzegorek, 2019, s. 141), który potem został zakodowany i uporządkowany według przyjętych kryteriów. Pragnę w tym miejscu jednak wyrazić krytyczną uwagę wobec odpersonalizowania badanych animatorów za sprawą nadanych im kodów, które mają postać dużej litery i cyfry (kobietom nadał dużą literę K oraz numer, mężczyznom dużą literę $\mathrm{M}$ oraz numer) i takimi kodami posługuje się, dokonując analizy narracji w wybranych kategoriach wymiarów w kolejnych rozdziałach. Autor powołuje się tu na zasadę anonimowości badanych. Myślę, że można było zamiast tych kodów nadać imiona czy pseudonimy animatorom i animatorkom biorącym udział w badaniach. Kłóci się to z moim postrzeganiem pedagogiki zorientowanej humanistycznie, a przecież ona stanowiła podstawę badań. Zabrakło mi w podrozdziale Teren badań i dobór przypadków uporządkowania w postaci tabeli czy pew- 
nego zestawienia osób biorących udział w badaniu pod względem płci, typu animatora (chóralny, teatralny, kabaretowy, klubowy etc.), obecni i dawni animatorzy. Ten porządek pozwoliłby w pewien sposób usystematyzować i zobrazować bogactwo animatorów ujętych w badaniach. Niemniej autor pozyskał obszerny materiał empiryczny (2087 stron maszynopisu z samych transkrypcji wywiadów; Grzegorek, 2019, s. 150), który dał podstawy do opracowania trzech rozdziałów empirycznych.

Pierwszy z rozdziałów części empirycznej pracy, Profile biograficzne badanych animatorów artystycznej kultury studenckiej w środowisku akademickim Szczecina to konsekwentna prezentacja przyjętych, jako jedne z kryteriów porządkujących materiał empiryczny, trzech wymiarów profili biograficznych, to jest: wymiar stawania się, wymiar bycia animatorem artystycznej kultury studenckiej oraz wymiar relacji pełnienia roli animatora artystycznej kultury studenckiej w stosunku do innych ról społecznych. Warte podkreślenia jest tu bogactwo wyłonienia grup animatorów ze względu na obraną drogę $\mathrm{w}$ wymiarze stawania się animatorem czy ze względu na charakter animacji (animacja kultury muzycznej, teatralnej, klubowej, senioralnej, radiowej, filmowej, literackiej czy wielodziedzinowej animacji) wyłonionych w wymiarze bycia animatorem.

Jako słabą stronę tego rozdziału uznaję relacjonowanie i opisywanie poszczególnych animatorów w obrębie danych grup z pozycji badacza (autor pisze w drugiej osobie o danym animatorze) szczególnie w dwóch pierwszych podrozdziałach, bez cytowania. Fragmenty narracji animatorów są dopiero $\mathrm{w}$ trzecim podrozdziale dotyczącym wymiaru relacji pełnienia roli animatora artystycznej kultury studenckiej w stosunku do innych ról społecznych. Tu też jest bogata lista 10 grup animatorów (sumiennego, zakonnika, personality, stratega, bojownika, rola wszechstronna, rola macierzyńska, animatora, ofiarowanie się, artysta) z całym bogactwem wielości pełnionych ról społecznych. To uwikłanie w wielość ról świetnie oddaje jedna z wypowiedzi dyrektor artystycznej chóru uczelnianego:

Ja mam gradację tych ról. Najgorsze jest zawsze dla mnie podziały i takie utożsamianie się z jakąś rolą, bo to zawsze w pewnym sensie ogranicza. Ja nie wiem, na czym polega mój fenomen. Może w odrobienie szaleństwa albo w temperamencie. Jedno i drugie jest nieuleczalne (Grzegorek, 2019, s. 287).

Jeszcze większą złożoność ról ujawnia narracja konsultanta muzycznego, pedagoga i wykładowcy uniwersyteckiego: 
Role się zderzają. To znaczy, ja jestem człowiekiem chaosu, więc muszę sobie zaplanować trasę. Jak idę do teatru, to do teatru i dlatego przydaje mi się Google. Ale jeżeli mam ci zaplanować drogę życiową czy działania artystyczne, co robię w przyszłym roku to nie, bo to telefon dzwoni i on cię w pewnym sensie determinuje. Bo twoją decyzją jest to, czy przyjmujesz zlecenie, czy przyjmujesz wyzwanie, czy nie. Przynajmniej tak mnie się zdarza. I jeżeli teraz pracuję na przykład z głuchymi i buduję z nimi meble do odbioru muzyki, to tworzę jakieś rzeczy, o których jeszcze rok wcześniej bym nie pomyślał, że robisz (Grzegorek, 2019, s. 289).

Zdaniem Grzegorka „wszystkie inne role społeczne stają w opozycji do roli artysty. Niejednokrotnie prowadzi to do porażek, w tym konfliktu ról i związanych z nim dylematów wyboru" (s. 618). Wielość ról pełnionych przez animatorów ujawnianych w licznie cytowanych fragmentach narracji animatorek i animatorów to wartość sama w sobie, ponieważ pozwala choć w części poznać różne światy ich życia codziennego - wielość kultur, przenikanie się ról społecznych w wielu wymiarach, które rysując się na linii pewnego kontinuum ujawniają się jako profil biograficzny, który jest też w pewnym sensie wymiarem historycznym, szczególnie w odniesieniu do byłych animatorów.

Piąty rozdział z kolei obejmuje analizę materiału empirycznego w obszarze profilu paradygmatycznego $\mathrm{w}$ wymiarze ideologicznym, teleologicznym, metodycznym, aksjologicznym i ewaluacyjnym. W podrozdziale nawiązującym do wymiaru ideologicznego autor wymienia sześć grup animatorów. Na drodze analizy autor wskazuje naczelną ideę animacyjną oraz jej rozwinięcie, co czyni do każdego z badanych w osobnych zestawieniach. Ten rozdział ujawnia bogactwo tych idei, choć jest tu po raz kolejny szczegółowy ich wykaz z minimalnym cytowaniem i refleksją samego autora. Nie rozumiem wyłonienia w kolejnym podrozdziale nawiązującym do wymiaru teleologicznego czterech grup badanych animatorek i animatorów w następujących układach z podziałem na pierwszo-, drugo- i trzecioplanowe wraz z ich ezemplifikacją:

(1) artystyczne, edukacyjne, społeczne; (2) artystyczne, społeczne, edukacyjne, (3) społeczne, edukacyjne, artystyczne, (4) edukacyjne, artystyczne, społeczne (Grzegorek, 2019, s. 360).

Autor zgodnie z przyjętym podziałem i kategoryzacją prezentuje z osobna cele każdego animatora przyporządkowanego do jednej z czterech grup. To bardzo żmudne zajęcie, dla mnie osobiście niemające sensu w przypadku 
tych różnorodnych konfiguracji celów działalności animacyjnej. Już wystarczająco bogata lista celów ujawnia złożoność tej działalności i nadawanie określonym z tych trzech grup celów rangi priorytetowej i zgodnie z tym prezentowanie tego ujawnia dużą drobiazgowość badacza, która zwyczajnie może męczyć.

Wymiar metodyczny działalności animatora artystycznej kultury studenckiej to podobny zabieg autora dokonującego podziału na cztery grupy animatorów i animatorek według typologii $\mathrm{H}$. Thery poprzez zidentyfikowanie gradacji zabiegów animacyjnych w odniesieniu do trzech procesów animacji: Proces twórczy - proces organizowania związków - proces odkrywania potencjałów w różnych konfiguracjach tych procesów. Po raz kolejny dla mnie jest to zabieg pozbawiony sensu, natomiast cenne jest w ogóle prezentowanie tych procesów w pracy animacyjnej.

Rozdział szósty obejmuje analizę materiału empirycznego w obszarze profilu osobowego w następujących wymiarach: cech temperamentu, cech intelektu, cech woli, cech społeczno-moralnych i innych cech animatora artystycznej kultury studenckiej. Autor bardzo syntetycznie prezentuje te cechy, odwołując się do narracji animatorów i animatorek.

To, co jest szczególne dla sposobu prezentacji poczynionych analiz, wyłonionych i scharakteryzowanych wymiarów w określonych profilach (biograficznym, paradygmatycznym, osobowym stanowiących trzy odrębne rozdziały) animatorów to fakt, że autor w obrębie każdej kategorii czy grupy konsekwentnie z przyjętym modelem typu animatora analizuje przypadek każdego z osobna, nie dokonując zestawień porównawczych. Rozumiem, że intencją autora było potraktowanie każdego przypadku animatora jako swoistego fenomenu, ale w wielu przypadkach animatorzy mają wspólne cechy i tak drobiazgowe prezentowanie wymagało naprawdę tytanicznego wysiłku zarówno po stronie autora tej pracy, jak i po stronie odbiorcy jako podmiotu poznającego (potencjalnego czytelnika) szereg szczegółów pracy animatora artystycznego. Autor właściwie w tych trzech rozdziałach ogranicza się do referowania przyjętych kryteriów, nie dokonując podsumowań ani wniosków na końcu każdego z rozdziałów. Rzadko także odwołuje się w nich do badaczy zjawisk kulturowych, kontekstów historycznych, społecznych, kulturowych, które są znaczące jako tło dla pewnych aspektów pracy animacyjnej, co też uznaję za słabą stronę tych rozdziałów. Niemniej jednak praca zawiera wysokie walory poznawcze w zakresie fenomenu samej animacji, jak i osób ją realizujących w środowisku akademickim. Wielość cytowanych narracji to także cenne materiały źródłowe. 
Te trzy rozdziały empiryczne stały się podstawą do wyłonienia ostatecznej typologii animatorów, która złożyła się na zakres siódmego rozdziału tej monografii. Autor wyłonił dziewięć typów animatorów spośród tych biorących udział w badaniu. Można z całą pewnością stwierdzić, że jest to rozdział podsumowujący wszystkie poczynione analizy, dzięki którym można było dokonać swoistej syntezy całej wiedzy uzyskanej w drodze realizowanych badań w zakresie animatorów artystycznej kultury studenckiej w środowisku akademickim.

W Zakończeniu monografii autor podkreśla, że:

Dzięki obszernym narracjom animatorów stało się możliwym ukazanie odrębności losów edukacyjnych, pierwszych kontaktów z kulturą artystyczną, inicjacji artystycznych, doświadczeń ze sztuką i działaniem akademickim. Udało się także określić postaci, które w życiu animatorów jawiły się jako osoby znaczące, mające niejednokrotnie decydujący wpływ na kreowanie dalszych decyzji dotyczących podejmowania przez badanych kształcenia i działania w obszarze kultury i sztuki (Grzegorek, 2019, s. 563).

Co szczególnie cenne, autor w Postulatach, których wysuwa wiele, jako ostatni podkreśla ideę:

(...) otwartego panelu dyskusyjnego animatorów artystycznej kultury studenckiej realizujących swoją działalność w środowisku akademickim Szczecina. Panel ten mógłby stać się stymulatorem do omawiania bieżących problemów, zainicjowania lepszej komunikacji między animatorami, między nimi a uczelniami i ich władzami, instytucjami kultury etc. Mógłby on umożliwić zaistnienie w szerszym dialogu odniesień i komentarzy do obecnej sytuacji i uwarunkowań pracy animatorów z dozą krytycznej refleksji wokół podejmowanych działań i związanych z tym deficytów (Grzegorek, 2019, s. 570).

Jak podkreśla prof. dr hab. Lech Witkowski, ta „praca ma istotne znaczenie praktyczne, wpływając na jakość analizowanych zjawisk w realiach akademickich" (Grzegorek, 2019, okładka książki).

Jest to też cenne źródło poznania bogatej, różnorodnej kultury akademickiej Szczecina jako miasta położonego w szczególnym miejscu, bo w bliskości Niemiec i krajów skandynawskich. Mieszkańcy Szczecina to głównie ludność napływowa (po zakończeniu II wojny światowej) z tradycjami i wzorami wielu kultur (duża mniejszość ukraińska, romska, grecka, białoruska etc.), które ze sobą wnieśli. Szczecin to także obecność wojsk Paktu Pólnocnoatlantyc- 
kiego (NATO) wraz z rodzinami żołnierzy, a zatem wielu kultur różnych nacji. O różnorodności kulturowej Szczecina świadczy fakt istnienia na jego terenie ambasad 13 państw. Szczecin zatem to szczególny teren dla edukacji międzykulturowej.

$\mathrm{Z}$ pełnym przekonaniem polecam tę monografię wielu środowiskom, szczególnie animatorom kultury, studentom kierunków artystycznych, artystom różnej „maści”, działaczom społecznym, nauczycielom, pedagogom kultury i badaczom kultury, wszystkim tym, którzy chcą działać i działają w różnych środowiskach, których celem jest integracja, ożywianie, uspołecznianie, uwrażliwianie na sztukę, poznawanie różnych światów za sprawą animacji kultury. Animacja jest jedną z form także edukacji międzykulturowej.

$\mathrm{Na}$ zakończenie pragnę podzielić się doświadczeniem czytelniczym. Jest to potężna pod względem liczby stron publikacja, pisana jednolitym tekstem, bez szczególnych wyróżnień (nieliczne kategorie były pisane dużą czcionką), bez śródtytułów czy wyróżnienia wyłonionych kategorii. Czytanie tak długiego tekstu bez specjalnych zabiegów redakcyjnych powoduje ogromny wysiłek przebrnięcia przez masę szczegółów, których nie szczędzi sam autor. Jest to jednak zarazem dowód ogromnego zaangażowania emocjonalnego, badawczego autora, który z artystycznego środowiska się wywodzi i w nim żyje i działa jako między innymi animator kultury.

\section{Bibliografia}

Czerepaniak-Walczak, M. 2006. Pedagogika emancypacyjna. Rozwój świadomości krytycznej człowieka. Gdańsk: GWP.

Grzegorek, J.N. 2019. Animatorzy artystycznej kultury studenckiej w środowisku akademickim. Typologia. Toruń: Wydawnictwo Adama Marszałek.

Laclau, E. 2004. Emancypacje. Wrocław: DSWE TWP.

Olbrycht, K. 2001. Wyzwania wobec kształcenia animatorów społeczno-kulturalnych. W: Gajda, J. i Żardecki, W. red. Dylematy animacji kulturalnej. Lublin: UMCS, ss. 111-117.

Roguska, A. 2012. Edukacja kulturowa wobec przemian globalizacyjnych i lokalnych. W: Roguska, A., Danielak-Chomać, M. i Dyrda, M.J. red. Edukacja kulturowa. Oczekiwania i potrzeby. Siedlce: Fundacja na rzecz dzieci i młodzieży „SZANSA”, ss. 21-57. 